\title{
SOCIAL CHANGE IN YOGYAKARTA: PAST AND NOW A SELO SOEMARDJAN PERSPECTIVE
}

\author{
Muhammad Iqbal Birsyada \\ University of PGRI Yogyakarta \\ Email: iqbal@upy.ac.id \\ Juang Kurniawan Syahruzah \\ University of PGRI Yogyakarta \\ Email: juang@upy.ac.id
}

\begin{abstract}
Abstrak
Yogyakarta merupakan salah satu pusat kebudayaan Jawa yang masih eksis baik nasional maupun internasional. Secara historis, perkembangan sosial dan budaya di era prakemerdekaan sampai era Reformasi mengalami perubahan sosial yang signifikan. Penelitian ini menganalisis dan menemukan proses perubahan sosial di Yogyakarta. Pendekatan perspektif Selo Soemardjan digunakan dalam menganalisis perubahan sosial di era pra-kemerdekaan di Yogyakarta. Sedangkan pada tahap kontekstual analisis fenomenologis sosial digunakan di Yogyakarta pada masa pasca kemerdekaan. Temuan dalam penelitian ini dialami dalam arti nilai dan budaya pada masa pra-kemerdekaan dan pasca-kemerdekaan. Orang-orang Yogyakarta yang telah meletakkan nilai etika budaya Jawa yang besar telah beralih ke budaya konsumtif, bisnis dan hedonis. Peran Sultan dan pemerintah kurang kuat dalam membendung berbagai arus yang masuk wilayah Yogyakarta. Pengendalian sosial lemah dalam membangun dan membendung nilai-nilai budaya yang tidak sesuai dengan norma etika masyarakat Yogyakarta lama. Saran dari penelitian ini adalah sosialisasi penguatan sistem sosial dan budaya dari pemerintah daerah ke tingkat terkecil masyarakat dan keluarga. Kedua, kebutuhan pemerintah untuk bekerja sama dengan organisasi masyarakat dalam memperkuat identitas budaya, etika dan norma agama masyarakat.
\end{abstract}

Kata kunci: Perubahan Sosial, Yogyakarta, Perspektif, Selo Soemardjan.

\begin{abstract}
Yogyakarta is one of Javanese cultural centers that still exist both nationally and internationally. Historically, social and cultural developments in the pre-Independence era until the Reformation era experienced significant social change. This research wants to analyze and find the process of social change in Yogyakarta. Selo Soemardjan's perspective approach was used in analyzing social change in the pre-Independence era in Yogyakarta. While at the contextual level of social phenomenology analysis used in analyzing the development of social change in Yogyakarta in the post-independence period. The findings in this study are that Yogyakarta experienced a sense of value and culture in the pre-independence and post-independence period. Yogyakarta people who previously put great ethical values of Javanese culture has shifted to the culture of consumptive, business and hedonist. The role of the Sultan and the government is less strong in stemming the various global currents that enter the territory of Yogyakarta. Social control is weak in building and stemming cultural values that are not in accordance with the ethical norms of the old Yogyakarta community. Suggestion of this research is socialization of social and cultural system strengthening from local government to the smallest level of society and family. Second, the need for government to work together with social organizations and religious communities in strengthening cultural identity, ethics and religious norms of society.
\end{abstract}

Keywords: Social Change, Yogyakarta, Perspective, Selo Soemardjan. 


\section{INTRODUCTION}

Culturally, the structure of Javanese society in the traditional period consists of King, Nobles and common people (Kuntowijoyo, 2016). The king owns and controls all the rights of the land within his territory. The relationship between kings and subjects is a symbiosis between patrons and clients. The royal family is often referred to as ndoro while the family servant is often called the abdi dalem. Political power of Java began to shift when post pecel pecinan at the beginning of the 18th century Mataram should be split into four parts of the kingdom of Kasunanan Surakarta, Mangkunegaran, Yogyakarta and Pakualaman Sultanate. The Giyanti Covenant and the Salatiga Covenant were a new milestone of Javanese politics during the Dutch colonial period (Wasino, 20008; Birsyada, et al, 2016).

Yogyakarta is one of the most important areas of Java's central power for the colonial. Yogyakarta since the Mangkubumi era or often referred to as Hamengkubuwono I until the 9th Hamengkubuwono leadership has an important bargaining position as a balance of power of the political power of other Javanese kingdoms such as Kasunanan Surakarta and Mangkunegaran. Politically, seeing the feudalism culture in the kingdom made the people of Yogyakarta easy to be controlled by the Dutch government. After the agreement between Giyanti and Salatiga, structurally in Yogyakarta during the colonial period there were three social classes. The first is an elite class consisting of Dutch colonial governorgeneral of the right of political authority and government in Java. Each of the Javanese kings who will ascend the throne shall obtain the approval of the Dutch Governor-General.

The second class is the aristocratic or noble group consisting of the king and his family. This group has self-managed lungguh land to support the economy of the royal family. In the 18th century the land belonged to the royal family was much rented out to the Europeans, and Chinese. Royal royalty and nobles are not accustomed to managing business because of the habit of doing business is the ethics of a Javanese nobles. Priyayi or noble only have the task of governing and not entrepreneur (Birsyada, et al, 2016; Birsyada, et, al, 2017). The most striking class differences can be seen in terms of grammar between European and indigenous people. Dutch officials and Europeans generally prefer to use their own culture and language rather than Javanese alus.

In the pre-independence period, social stratification in Yogyakarta was very visible. Social stratification can be seen from the functional relationship through the position of a person. 
Europeans usually occupy the highest positions as experts who earn far higher salary than the natives. They usually work as managers in companies built by colonial and royal governments. Examples are on the development and development of sugar mills. The highest responsibility holders are from Europeans. Indigenous people must be satisfied just to be a typist and hired laborer or coolie who wages a very small wage. The king and his family have no power to control the social stratification system that has been standardized by the colonial government. The king and his family receive only the profit sharing from the sale of the economic products they manage (Soemardjan, 2009).

Social stratification can also be seen from the educational system built by the colonial government. The Europeans and their Chinese have their own level of education that is managed in a modern way. They set up special schools of Europeans with European language introductions. While natives are not given the same rights to modern education as the Europeans and Chinese. The impact of this is that in the nineteenth century there were still many natives who experienced what was then called illiteracy. Natives were the lowest class in the hierarchy of social stratification in Yogyakarta in the 19th and early 20th centuries. Natives were almost impossible to occupy important positions in the
Dutch East Indies government without the genealogy of the royal family (Van Niel, 1984).

Some of the most complete literature on social change is a work entitled Social change in Yogyakarta by Selo Soemardjan Early is considered the most monumental work that is able to see more deeply how the social conditions of Yogyakarta in the era of Dutch colonial rule. Theoretically, Soemardjan's ideas further developed Durkheim's theory of social solidarity. Traditional conditions can be seen through mechanical thinking while modern organic constructions are characterized by a systematic functional division of labor. The social changes that occurred in Europe due to the industrial revolution that made manpower replaced with engine power which then gives a significant impact on the shift of old values and norms into new values (Soemardjan, 2009).

While the new norms that are formed are not yet established. Another significant impact is that individuals no longer have an ideal standard of norms in responding to the challenges of rapidly moving social change. In theoretical conception, according to the Durkheim tradition it is later called Anomie. At this time the individual has lost his old norms which are then replaced by new norms which in practice have not been fully established. With other undesired 
changes often occur. In terms of responding to social change, the people of Yogyakarta experienced a very massive cultural struggle between accepting modernization and rejecting modernization. The third position is to blend the local cultural values of modern culture brought by the west.

According to Soemardjan (2009) in the case of Yogyakarta social change began to emerge due to the modernization done by the Dutch colonial government against the Java community, especially Yogyakarta. The change begins by altering the construction of the previously mechanistic thinking of the society into an organic one. Historically, during the feudal period of Javanese kingdom, the people were totally unaware of the so-called division of labor. The colonial government changed the system of government from the former centralist to the king as the sole authority holder of a decentralized democratic authority. The change of the system made the people of Yogyakarta into three typologies. First is able to adjust to the new system. Second, adapt slowly. The three are incapable of following the changes of the system. Socio-politically, in the context of Yogyakarta, the social changes experienced by society during the three ages of Dutch colonial rule, Japan and NKRI are influenced by two equally powerful agents. The first is Sultan
Hamengkubuwono IX. The second is the educated elite. The political hierarchy of the Sultan's position at that time was under the control of the Dutch colonial government's orders. But culturally, the power of Sultan HB IX is considered absolute or absolute according to the people of Yogyakarta. Things that are not predictable by the colonial government is the people of Yogyakarta to know what is called Sabdo Pandito Ratu which means is the word or speech of the Sultan is an absolute and well regarded by the people of Yogyakarta.

The above means that culturallysymbolically, in the construction of Javanese culture has been embedded for a long time if Sultan is none other than as a representative of God on earth as well as protector of religion (sayyidin panotogomo). Thus the construction greatly impacted on the legitimacy of the Sultan's power considered higher and the prestige than the Dutch colonial government order. The people of Yogyakarta against every word of the Sultan who is considered good is not a word other than saying sendiko dawuh. Against the speech of the Sultan the people accept it for what it is and carry it out voluntarily. This thing then called the Sultan acts as an agent of social change for the people of Yogyakarta.

\section{RESEARCH METHODS}


This research uses discrete analysis through critical discourse approach. The first researcher conducted a study of relevant literature on the theme of research which was then compared with other relevant sources. The discourse of critical discourse is then undertaken to understand the various descriptions through the search of historical sources and social phenomena of the Yogyakarta community. Selo Soemardjan's perspective was used to map social change in Yogyakarta. However, the perspective will be analyzed again through the discourse of critical discourse by comparing the social conditions of Yogyakarta society in the post-independence era of modern contextual. Thus will be found a new construction of social change in Yogyakarta in the present era. This research also uses social phenomenon approach to see the social reality of contemporary social life of Yogyakarta society at this time. Thus will be obtained construction of social change intact between the past with the present.

\section{RESEARCH FINDING AND DISCUSSION}

Socio-historically, the role of the king in Yogyakarta other than as a local elite is the holder of the authority of cultural power. If the Sultan is the source of the peoples of Yogyakarta then the second as the agent of social change is the student elite. This student elite according to Soemardjan served as a communicator between the words of the Sultan with the people of Yogyakarta. The student elite is actively pursuing a process of awareness of the people, especially the illiterate farmers, to prepare for a revolutionary social change. Students elite is then able to make the process of awareness as well as change the mindset of farmers who had considered change as a negative and destructive to be positive and acceptable with the field of chest (Soemardjan, 2009).

When the Dutch and Japanese authorities in Yogyakarta have collapsed, Sultan HB IX took power. The takeover attitude is considered the most appropriate and has the support of all the people of Yogyakarta. The impact of this is the relationship between the palace and the people getting closer. After Sultan HB IX took power then continued with a more modern and democratic system of government change. Sultan began to divide his power by legalizing the role of DPD. The impact of the division of power is a shift in the value of nobility and nobility in Java. If in preindependence the position and social status of the Javanese nobility or priyayi can be attained from generation to generation and can automatically occupy important positions within the 
government (Wasino, 2008; Birsyada, et al, 2016). However, in the postindependence era new values emerged more democratic that is about achieving the position and social status of the community to occupy an important position in the government can be done by anyone according to the capacity level of education and professionalism.

On these moments the royal and nobles many decreased Mobility while the educated lower classes experience vertical social mobility. Thus the new system opened the door as wide as possible for the entire people of Yogyakarta to occupy an important position in the government. This then led to many circles from outside the kingdom who became new officials in the government bureaucracy and defeated the uneducated noble or priyayi. This event then led to new elites in the social structure of Yogyakarta society. The new elite is dominated by scholars. While the other status of Javanese titles degenerate. At this time many lower classes who want their children to rise to social status become government employees willing to sell their fields, land and livestock to send their children to occupy important positions in government (Soermardjan, 2009).

Starting from the above explanation can be explained if education is one of the most rational way to raise the social status of lower class society occupy the government. This is also offset by changes in the grammatical system from the original is the Java language into Indonesian as the everyday language in the government of Yogyakarta. The use of Indonesian language is a form of the absence of strata in Yogyakarta society. Indonesianwas used in the palace to communicate with the Sultan. The relationship between the government and civil service-even more egalitarian. Thus there is a cultural shift from the old feudalistic culture to an egalitarian culture. The pattern of communication in the structure of government no longer uses the Java-Java kromo loud-toothing language that is too complicated. But the pattern of daily communication use the Indonesian language.

Culturally, Yogyakarta as one of Javanese cultural centers apart from Solo has significant cultural significance to manage people's lives (Wasino, 2006). These cultural meanings are an identity that strives to be firmly prevented and developed in the daily life of its citizens. The people of Yogyakarta cannot be separated from the deeply rooted Javanese philosophy and culture. The character of patience, rila, narima, vigilant, elo, noto roso, andhap asor, wani ngalah, caring behavior and loneliness gamely attached in the values of society, especially Yogyakarta which is one of the center of Javanese culture. 
This then gives the identity of Wong Jowo who has the nature of Njawani (Mulder, 2001). The Javanese emphasize simple, tolerant, patient and ascetic life.

The idea of ethical philosophy in the Javanese Society is widely practiced in Yogyakarta is to be a selfless "selfless" person committed through advice to carry out values such as rila (unbound), narima (being grateful for life as it is), wapadaeling (Continuous recall), andhap ashor (humble), prasaja (earthy), the other way is by living a lot of concerned about the conduct of conduct "behavior" of life. The Javanese people know who is harmonized in ethics in the life of society. Having self-control subdues human emotions and drives. This ethical rule is done for the harmony of the overall existence of the harmony of life in life.

Essentially, the social philosophy of the Javanese society the necessity of humans to achieve harmony of the maintenance of order. So that personal desire, ambition, and lust are perceived to threaten harmony, to the point that the idea that sacrifice for social harmony will lead to the highest reward. One is better to succumb to society than to impose his will (Mulder, 2001: 67-68). While in view Suseno (1985) Javanese society has a special characteristic of ethics and the construction of philosophy which became the basic guidelines in social life. Among these ethical principles are: the principle of harmony, the principle of respect and ethics of social harmony. In short, the Javanese society has a construct of life-balance thinking between micro and macrocosm. Indirectly the Javanese society strongly emphasized the harmonization between the universes with jagad cilik and jagad gede.

Construction of ethics and dimensions of Javanese philosophy can also be seen in several works of Javanese literature that many contain the dimensions of the wisdom of Javanese life view idealistically. In the narrative of historical literature, for example, the values and ethics of Java can be seen from the content of stories that contain many pitutur noble science as well as symbolically teach the values of teaching manunggaling kawula lan gusti (Birsyada, 2016). In Babad Tanah Jawi Ras, JJ (1987), for example, tells the local wisdom of ethical and moral values in the form of story of the relationship between kawula and gusti or the people with their king (Rishi, 2007; Rishi, 2010). While on Babad Jaka Tingkir more to challenge the tradition (Florida, 2003). Wedatama fibers are more spiritual and mystical (Mangkunegaran IV, 1926).

Koentjaraningrat (1994: 229-235) explains that Javanese in general in urban society consists of two social classes. The first is the lower class called tiyang alit. They work as farmers, rough laborers, market traders and sellers of suburban stalls. The second class is a 
priyayi class or clerk. The merchant class is usually named with Sodagar they work in agriculture and home industry. They usually hold firm Islamic traditions. They do not like slametan ceremonies, kenduren sessions, and the like. On the contrary, the prijaji class is very concerned with culture like likes puppets, sarasehan, kenduren and soon. While in the perspective of Hefner (1999) Java society consists of two parts of culture. The first culture is the Java Mountain. While the second culture is a culture of coast people.

Ideologically, Resi (2007: 2010) explains that the Javanese will always maintain the harmony and balance of various elements that exist (micro and macro kosmos). With so the life of the universe will be safe again, peace and serenity is the dream of life and purpose of life of the Javanese "memayu hayuning bawana". The teaching of life balance is nothing but the essence of the concept of ideological ideology of manunggaling kawula lan gusti. Sociologically, the teaching is not only a vertical meaning in which the human relationship with God is involved. However, the conception also means the unreliability of social relations between man and the surrounding community, including the violence between the people and the government.

Philosophically, even in an ideal philosophical level Javanese society is concerned with simplicity, tolerance, ascetic, humility, rila, narima and legawa, but in the current level of reality is not so. Yogyakarta as a cultural center, education and struggle at present has changed a lot. Yogyakarta, where the Javanese community resides, has undergone a very rapid change after the 2000s. Yogyakarta has become a business city with metropolitan culture. A number of shopping malls like Mall or Plaza offer different consumer goods and lifestyle than ever before. Yogyakarta as a small town at least filled with 4 big Plaza and 6 Mall and several hypermarkets, now offers a new, more modern, metro politic and consumptive lifestyle. A lifestyle is different from the ideal lifestyle of the Javanese.

Almost every weekend of Yogyakarta is flooded by domestic tourists from various parts of the archipelago causing traffic congestion along the way. The congestion can be seen on week nights along the road to the palace and Malioboro. Not only inside the city, in the ring road is traffic congestion accustomed to happen. Mass transit like Trans Jogja inside the city often cannot move because of traffic congestion in the middle of the city. The impact of it is a wait queue at each bus stop for a very long time and the passengers are so busy. The emergence of uncontrolled online transportation has increased the list of traffic congestions across the corner of the city. Student lifestyle in Yogyakarta 
has also changed a lot into the metropolis. The burgeoning of online transportation also affects the reduction of traditional transport revenues such as andong and Pedi cap

Many foreign tourists to Yogyakarta indirectly also affect the shifting lifestyle of young people in Yogyakarta. The scenery can be seen in the evenings along the Prangtritis Road composing the elite class cafes that many foreign tourists visit. In addition, the youngsters of Yogyakarta come to the end of the lifestyle. Young boys began to party singing, men and women all smoked and drank alcoholic beverages outright. The places of cafe, inns, and covert accommodation that are usually used for dating are also available in various places in Yogyakarta. Among the areas are: Sosrowijayan, Parangkusumo and Pandansimo district.

In the southern part of Bantul there are tombs and pet kramat Sheikh Maulana Maghribi, Sheikh Belabelu around Parangkusumo also around the area there are many inns, cafe and lodging. Every Tuesday night kliwon and Friday kliwon usually where the place is visited by many young people from various regions. In the Depok area of Sleman Nogolaten behind Amplaz there are also many dangdut music special cafe-cafes that are not rare in some times. Another issue that often appears on the surface is a parking lot dispute along the way. Wild parking lots have become a struggle between groups of people who feel dominated by one particular area of parking. Typically parking area is managed by one of the thugs in charge of the area. They have some members who are structured neatly.

These lifestyle changes have caused reactions from the Yogyakarta community themselves. Firstly, those who oppose the metropolis, consumptive and hedonistic lifestyles are considered contradictory to the old values of Javanese culture. Secondly, those who compromise with the inclusion of various cultures are coming in Yogyakarta but are still in the context of separation adjusted to the identity of noble values. Thirdly, those who receive the total of various cultures that come include metropolis, hedonic, consumptive culture. Each of these supporters articulated them in everyday lifestyles. Even in the community of study is often held at cafes, malls or elite class places around Yogyakarta.

At praxis level, the change of Yogyakarta's previous Njawani changed to Brangasan with the emergence of various clashes committed by individuals who are notabennya still Sitting in school. Njawani is a lifestyle of Javanese people who prioritize inner harmony and social violence. This is evidenced by the attitude of manners, manners and manners of all people. While brangasan is 
a selfish attitude of putting forward personal ego and tending to lead to social violence. Klitih is an action of group or individual that leads to violent and criminal behavior. The climatic phenomenon in Yogyakarta, which is a large part of the underage culprit is a real blow to the previously famous and peaceful inhabitants of Yogyakarta.

Klitih started to discover when the case was killed teenager named Adnan Hafid Pamungkas (20) that occurred on West Ring road, Salakan, Trihanggo, Gamping, Sleman on Friday 30 September 2016 at 00.30 in the morning allegedly because klitih person. Hafid was the victim of the stabbing of an unknown young man. The victim dies after the sharp weapon (sajam) the perpetrator penetrates the victim's chest (accessed from

http://jogja.tribunnews.com/2016/09/30 /ini-the-fitness-of-complement-of-thebanban-action-klitih-di -ring road-westmoment-seconds-stabbing on April 12, 2017).

Based on the results of crime scene and some testimony of witnesses, the beginning of this incident is due to accidental victim who fights with hordes of motorcyclists hardened the sound of his motorcycle. Other clit events are also experienced by junior high school students (SMP) Piri 1 Yogyakarta. The perpetrators were arrested by police on 14 March 2017. As a result of the clit victims, Ilham Bayu Fajar (17) had to stretch his life after being hit by his brother Fernando Suryo Pangestu (19) on Sunday at around 00.30 on Jalan Kenari, Mayor of Yogyakarta. The incident began when Itham and his brother Fernando played with five other colleagues on Jalan Solo, playing pool together. When finished, the group decided to go home because it was late at night. On the way home, the entourage stopped at the Brimob headquarters. There, Ilham could immortalize his last moment by making a video with his colleagues. Suddenly a mob of unknown people blindly slashed his brother until he was seriously injured. Even cut wounds that Ilham suffered to penetrate his right chest, which automatically injured the lung parts of the victim (accessed from http://jogja.tribunnews.com/2017/03/14 /realtime-news-polisi-pangkap-pitaku klitih- On-street-walnut-Yogyakarta on April 12, 2017). In this case have been set as many as six suspects.

Based on the results of the above case examination, it was found that 6 suspects from 8 of them were AA (17), FF alias Surya (16) as executor, TP (13), JR (14), MK (14), RB (18) NS (20) and Af (15). He explained that this bribe case was made into three files based on the role of the suspect. The suspects were charged with Article 338 of the Criminal Code on murder, Article 170 of the Criminal Code on joint violence, Article 351 of the 
Criminal Code on ill-treatment (accessed fromhttp://jogja.tribunnews.com/2017/ 03/21/berkas-perkara-case-kitih-atkenari-street yogyakarta-alreadysubmitted-to-jpu on 12 April 2017).

Clerical events also occur at the station Jalan Magelang, Mlati on Friday March 17, 2017. According to the narrative from several sources, klithih action often start without cause. Like "When the contents of gasoline, casualties and two perpetrators look at each other, do not feel a perpetrator attacked the victim using a helmet,". Residents who saw the fight tried to intervene. Seeing this, another actor, named Gretta (22) suddenly issued a sharp weapon type machete. He held up his machete intending to scare off the crowd. But as more and more crowds came, the suspect ran away. Gretta who is a citizen of Kricak, Tegalrejo, Yogyakarta can be arrested by the community. Luckily patrol from Ms Mlati police pass, and immediately secure the suspect before the masses added violent (accessed from http://jogja.tribunnews.com/2017/03/17 /seorang-pelaku-aksi-klitih-kabur-saatdanan-dimimi- Residents on April 12, 2017).

The arrest will be the act of klitih committed by the Blessed Police on Wednesday, March 29, 2017. Police secured four youths who allegedly will perform klitih action. The perpetrators who were secured were IN alias Iwan (29), Temanggung resident, HR alias Herdi (16), Banguntapan residents, OY aka Yoga (20), citizens Sendangadi, Mlati Sleman and BP alias Bayu (24), Umbulharjo Yogyakarta. Berbah Chief of Staff, Kompol Suhadi, said the arrest of the four youths stems from officers' suspicions during the patrol and sees two motorcycles passing without a license plate. One motor is not installed, and the other plates of the number are accidentally closed with stickers. Once aware of the existence of police, the perpetrators step on the gas escape until finally happened chase. Arriving in front of Masjid Maulani Kalitirto Berbah, they can be arrested by the police. When the search was conducted, the officer found a cell phone unit that allegedly resulted in a crime. (Accessed from http://jogja.tribunnews.com/2017/03/31 /polsek-behavior-trampled-the-with-themoney-whois-wedged-will-act-the-clearcomer on the 12th of March 2017).

\section{ANALYSIS AND CONCLUSION}

Yogyakarta has undergone social change as well as a shifting cultural shift. There is a shift in the culture and lifestyle of society. First, the culture of manners, njawani, gemi and putting value and ethics have been Shifting to the culture of consumptive, hedonic and brutal. The people of Yogyakarta and the local government cannot stem the flow of 
global culture that goes to Yogyakarta. Thus the power of community control at grass roots level is considered weak. Secondly, Yogyakarta with its many malls, plazas, hotels and cafes from the top to the bottom makes this city shifted from the strengthening of culture to be more likely to segment business and tourism. Third, the proliferation of cafes, inns and cloistered hotels indicates that there is a new culture among youth of Yogyakarta that is increasingly away from the norms and ethics of Javanese culture.

Fourth, klitih phenomenon in Yogyakarta proves that social facts show some of the generation of students in Yogyakarta there are social deviations that lead to physical violence. This shows that social control and educational institutions are very weak. Fifth, Selo Soemardjan's analysis of social change in Yogyakarta in the past when contextualized at this time has undergone many cultural shifts. If the former Sultan and the elite of students are able to become the main actors of Yogyakarta social change towards the modern and egalitarian era. At this time the role of Sultan and student elite is less dominant in facing the global cultural power that goes to Yogyakarta. Even in some time ago the Sultan got opposition from relatives and the public about the Sultan's word that judged to violate Paugeran.
The number of educational institutions from basic level to university in Yogyakarta is not necessarily directly proportional in addressing and reinforcing the cultural identity of Yogyakarta as the center of Javanese culture. The entry of online transport in Yogyakarta also shifts local transportation such as pedicab and carrier which previously characterized the identity of culture-based transportation. Suggestion in this research is Yogyakarta government begin to strengthen social system and governance until RT / RW level in reinforcing social control as well as the cultural values and cultural identity of Yogyakarta. The strengthening of the lower middle class economy needs to be strengthened to build a strong socioeconomic community base. Fourth, in collaboration with various institutions of religious social organizations to strengthen the social and religious system of Yogyakarta society that has strong cultural character values.

\section{REFERENCES}

Birsyada, Muhammad lqbal, 2012. Peristiwa Konflik Pecahnya Keluarga Di Kerajaan Demak Dalam Persepsi Penulis Babad. Tesis UNNES.

Birsyada, Muhammad lqbal, 2016. Islamisasi Di Jawa: Konflik Kekuasaan Di Demak. Yogyakarta: Calpulis.

Birsyada, Muhammad lqbal, dkk, 2016. Pemikiran Keluarga Mangkunegaran. Jurnal Pramita 
Jurusan Sejarah Universitas Negeri Semarang volume 2 .

Birsyada, Muhammad lqbal, dkk, 2016. Bisnis Keluarga Mangkunegaran, Jurnal Penelitian Sosial dan Keagamaan Universitas Islam Negeri Walisongo Semarang volume 1.

Birsyada, Muhammad Iqbal, 2016. Budaya Keraton Pada Babad Tanah Jawi Dalam Perspektif Pedagogi Kritis, Jurnal Sejarah, Budaya dan Pengajarannya Universitas Negeri Malang nomor 2 tahun 2016.

Florida, Nancy K. 2003. Menyurat Yang Silam Menggurat Yang Menjelang Sejarah sebagai Nubuat di Jawa Masa Kolonial. Yogyakarta:Bentang Budaya.

Hefner, Robert W, 1999. Geger Tengger Perubahan Sosial dan Perkelahian Politik. Yogyakarta: LkiS.

Koentjaraningrat, 1994. Kebudayaan Jawa. Balai Pustaka, hlmn 229-235.

Kuntowijoyo, 2016. Raja, Priyayi dan Kawula. Yogyakarta: Ombak.

Mangkunegara IV. 1926. Serat Wedatama Cetakan Pertama. Kediri: Tan Khoen Swie.

Mulder, Niels, 2001. Mistisisme Jawa Ideologi Di Indonesia. Yogyakarta: LKiS. Halaman 67-68.

Resi, Maharsi, 2007. Babad Kraton Analisis Simbolisme Struktural Upaya Untuk Memahami Konsep Berpikir Jawa Islam. Desertasi: UIN Sunan Kalijaga.

Resi, Maharsi, 2010. Islam Melayu vs Jawa Islam. Yogyakarta: Pustaka Pelajar.

Soemardjan, Selo, 2009. Perubahan Sosial di Yogyakarta. Jakarta: Komunitas Bambu

Suseno, Franz Magnis, 1985. Etika Jawa sebuah analisa falsafi tentang kebijaksanaan hidup Jawa. PT. Gramedia: Jakarta.

Van Niel, Robert, 1984. Munculnya Elit Modern Indonesia. Jakarta: Pustaka Jaya.
Wasino, 2006. Wong Jawa dan Wong Cina: Liku-liku hubungan sosial antara etnis Tionghoa dengan Jawa di Solo tahun 1911-1998. Semarang: Unnes Press.

Wasino, 2008b. Kapitalisme Bumi Putra: Perubahan Masyarakat Mangkunegaran.

Wasino, 2012. Modernisasi Pemerintahan Praja Mangkunegaran Surakarta. Jurnal Paramita volume 22 nomor 1 januari hlm.25-40. Yogyakarta: LkiS.

Wasino, 2014. Modernisasi Di Jantung Budaya Jawa Mangkunegaran 18961944. Jakarta: Kompas. 
Social Change In Yogyakarta: Past and Now..., Muhammad I.B \& Juang Kurniawan S., 